\title{
Susceptibility patterns and the role of extracellular DNA in Staphylococcus epidermidis biofilm resistance to physico-chemical stress exposure
}

\author{
Charles Ochieng' Olwal', Paul Oyieng' Ang'ienda, David Miruka Onyango and Daniel Otieno Ochiel
}

\begin{abstract}
Background: Over $65 \%$ of human infections are ascribed to bacterial biofilms that are often highly resistant to antibiotics and host immunity. Staphylococcus epidermidis is the predominant cause of recurrent nosocomial and biofilm-related infections. However, the susceptibility patterns of $\mathrm{S}$. epidermidis biofilms to physico-chemical stress induced by commonly recommended disinfectants [(heat, sodium chloride $(\mathrm{NaCl})$, sodium hypochlorite $(\mathrm{NaOCl})$ and hydrogen peroxide $\left(\mathrm{H}_{2} \mathrm{O}_{2}\right)$ ] in domestic and human healthcare settings remains largely unknown. Further, the molecular mechanisms of bacterial biofilms resistance to the physico-chemical stresses remain unclear. Growing evidence demonstrates that extracellular DNA (eDNA) protects bacterial biofilms against antibiotics. However, the role of eDNA as a potential mechanism underlying S. epidermidis biofilms resistance to physico-chemical stress exposure is yet to be understood. Therefore, this study aimed to evaluate the susceptibility patterns of and eDNA release by S. epidermidis biofilm and planktonic cells to physico-chemical stress exposure.
\end{abstract}

Results: S. epidermidis biofilms exposed to physico-chemical stress conditions commonly recommended for disinfection [heat $\left(60^{\circ} \mathrm{C}\right), 1.72 \mathrm{M} \mathrm{NaCl}$, solution containing $150 \mu \mathrm{L}$ of waterguard $(0.178 \mathrm{M} \mathrm{NaOCl})$ in $1 \mathrm{~L}$ of water or $1.77 \mathrm{M} \mathrm{H}_{2} \mathrm{O}_{2}$ ] for 30 and 60 min exhibited lower log reductions of CFU/mL than the corresponding planktonic cells $(p<0.0001)$. The eDNA released by sub-lethal heat $\left(50^{\circ} \mathrm{C}\right)$-treated $\mathrm{S}$. epidermidis biofilm and planktonic cells was not statistically different $(p=0$. 8501). However, $50^{\circ} \mathrm{C}$-treated S. epidermidis biofilm cells released significantly increased eDNA than the untreated controls $(p=0.0098)$. The eDNA released by $0.8 \mathrm{M} \mathrm{NaCl}$-treated $\mathrm{S}$. epidermidis biofilm and planktonic cells was not significantly different $(p=0.9697)$. Conversely, $5 \mathrm{mM} \mathrm{NaOCl}$-treated $S$. epidermidis biofilms exhibited significantly increased eDNA release than the corresponding planktonic cells $(p=0.0015)$. Further, the $50 \mu \mathrm{M} \mathrm{H}_{2} \mathrm{O}_{2}$-treated S. epidermidis biofilms released significantly more eDNA than the corresponding planktonic cells $(p=0.021)$.

Conclusions: S. epidermidis biofilms were less susceptible to physico-chemical stress induced by the four commonly recommended disinfectants than the analogous planktonic cells. Further, S. epidermidis biofilms enhanced eDNA release in response to the sub-lethal heat and oxidative stress exposure than the corresponding planktonic cells suggesting a role of eDNA in biofilms resistance to the physico-chemical stresses.

Keywords: Staphylococcus epidermidis, Bacterial biofilm, Susceptibility patterns, Extracellular DNA, Physico-chemical stresses

\footnotetext{
* Correspondence: olwalco@gmail.com

Department of Zoology, School of Physical and Biological Sciences, Maseno

University, P.O. Box, 333-40105, Maseno, Kenya
}

(c) The Author(s). 2018 Open Access This article is distributed under the terms of the Creative Commons Attribution 4.0 International License (http://creativecommons.org/licenses/by/4.0/), which permits unrestricted use, distribution, and reproduction in any medium, provided you give appropriate credit to the original author(s) and the source, provide a link to the Creative Commons license, and indicate if changes were made. The Creative Commons Public Domain Dedication waiver (http://creativecommons.org/publicdomain/zero/1.0/) applies to the data made available in this article, unless otherwise stated. 


\section{Background}

A bacterial population exists either as planktonic (freefloating cells) or as biofilm [1]. Bacterial biofilm refers to a sessile cluster of bacterial cells encased in a selforiginating extracellular matrix (ECM) [2] composed of polysaccharides, proteins, water, lipids and nucleic acids [1]. Bacterial biofilms are ubiquitous and cause over $65 \%$ of human infections [3]. Moreover, bacterial biofilms are less susceptible to antibiotics and host immunity $[4,5]$. Staphylococcus epidermidis is a Gram-positive coagulase negative bacteria most commonly linked with nosocomial and biofilm-related infections [6]. S. epidermidis adopts a biofilm lifestyle that enables resistance to antibiotics and host immunity, which potentially could lead to severe conditions such as bacteremia and sepsis, and if left untreated could result in death [7]. Up to $80 \%$ of infections of medical implant devices such as central venous catheters, cardiac pacemakers, tissue fillers, intrauterine devices and joint prostheses are caused by S. epidermidis biofilms [8].

Several studies have compared the susceptibilities of biofilm and planktonic forms of bacterial species to various physico-chemical stresses. For instance, studies have reported that biofilm forms of Mycoplasma bovis [9], Vibrio cholerae O1 [10], Salmonella enterica [11], Burkholderia cenocepacia [12], Lactobacillus plantarum subsp. planturum [13] Pseudomonas aeruginosa [14], Mycobacterium avium, Mycobacterium intracellulare [15] and Klebsiella pneumoniae [16] are more resistant to various conditions of heat, osmotic and oxidative stress exposure than the respective planktonic forms. In contrast to the bacterial species above, S. epidermidis biofilm is the most clinically relevant and a model of bacterial biofilm infections [17]. However, the susceptibility patterns of $S$. epidermidis biofilms to physicochemical stresses commonly recommended for disinfection of food, drinking water, surfaces and medical equipment in domestic and human healthcare settings remains largely unknown.

The molecular mechanisms underlying bacterial biofilms resistance to stress agents remains largely unclear [18]. It is thought that mechanisms such as limited diffusion across the ECM barrier, the slow growth rate of biofilm cells, overproduction of antibiotics' neutralizing enzymes, physiological heterogeneity of biofilms, the presence of persister cells and adaptive stress responses contribute to the high bacterial biofilm resistance $[1,3]$ against antimicrobials. However, the above mechanisms not only inconclusively explain the resistance of bacterial biofilms to antibiotics but also apply to a limited bacterial species $[1,6]$. Growing evidence is beginning to link extracellular DNA (eDNA) of genomic origin released via active secretion or controlled cell lysis [19] with microbial biofilm resistance to various stress agents. For instance, eDNA has been shown to protect S. epidermidis, Staphylococcus aureus and Actinobacillus pleuropneumoniae biofilms against antibiotics such as vancomycin, $\beta$ lactams and penicillin G respectively [20-22]. Furthermore, a study reported that eDNA protects Candida albicans biofilm against $5 \mathrm{mM}$ hydrogen peroxide $\left(\mathrm{H}_{2} \mathrm{O}_{2}\right)$ stress [23]. The release of eDNA via lysis of a subpopulation of cells is a common phenomenon throughout the life cycle of biofilm-forming bacteria such as S. epidermidis [19]. However, the role that the released eDNA plays in $S$. epidermidis biofilms resistance to physico-chemical stress exposure is yet to be understood.

Therefore, the present study aimed to evaluate the susceptibility of and the eDNA release by $S$. epidermidis biofilm and planktonic cells to physico-chemical stress exposure.

\section{Methods}

Sample collection, bacterial isolate and growth conditions The study was conducted between November 2015 and January 2017. S. epidermidis isolates were obtained by swabbing arm joints of seventy-one outpatients at Kisumu County Hospital, a referral health facility in western Kenya using a protocol described in [24]. A swab from each outpatient was plated on mannitol salt agar (MSA) (HiMedia Laboratories Pvt. Limited, Nashik, India) and then incubated for $24 \mathrm{~h}$ (hours) at $37^{\circ} \mathrm{C}$. One $S$. epidermidis isolate (largest colony) from the MSA plate was inoculated into $2 \mathrm{~mL}$ Tryptic Soy Broth (TSB) (Sigma Aldrich Chemie GmbH, Steinheim, Germany) and incubated at $37{ }^{\circ} \mathrm{C}$ with shaking at 120 revolutions per $\min (\mathrm{rpm})$ for $18 \mathrm{~h}$ to form $S$. epidermidis suspension. Biofilm-forming ability of each of the S. epidermidis suspension was assessed using the tube method biofilm assay as described in [25]. Only sixty-two S. epidermidis suspensions that were capable of forming biofilms were used in the present study.

A pair of S. epidermidis biofilm and planktonic cultures was generated from the biofilm-forming suspension as described in [26] with few modifications. Briefly, to generate S. epidermidis planktonic culture, $100 \mu \mathrm{L}$ of the S. epidermidis suspension was inoculated into $10 \mathrm{~mL}$ fresh TSB (Sigma Aldrich Chemie GmbH, Steinheim, Germany) in conical polystyrene tube and then incubated at $37{ }^{\circ} \mathrm{C}$ with shaking at $120 \mathrm{rpm}$ for $18 \mathrm{~h}$. To generate S. epidermidis biofilm culture, $100 \mu \mathrm{L}$ of the S. epidermidis suspension was transferred to a conical polystyrene tube containing $10 \mathrm{~mL}$ fresh TSB (Sigma Aldrich Chemie GmbH, Steinheim, Germany) supplemented with $1 \%$ glucose (Unilab Limited, Nairobi, Kenya) to induce biofilm formation and then incubated at $37^{\circ} \mathrm{C}$ with shaking at $120 \mathrm{rpm}$ for $24 \mathrm{~h}$. In this study, S. aureus American Type Culture Collection (ATCC) 29,213 was used as a reference strain due to its good biofilm-forming ability within $24 \mathrm{~h}$ [27]. 
Susceptibilities of S. epidermidis biofilm and planktonic cells to physico-chemical stress induced by the commonly recommended disinfectants

Based on the recommended guidelines for routine disinfection in domestic and human healthcare settings, the following physico-chemical stress conditions were used: heat $\left(60{ }^{\circ} \mathrm{C}\right)$ [28], $1.72 \mathrm{M}$ sodium chloride $(\mathrm{NaCl})$ [29], $150 \mu \mathrm{L}$ of waterguard in $1 \mathrm{~L}$ of water [30] and $1.77 \mathrm{M}$ $\mathrm{H}_{2} \mathrm{O}_{2}$ [31]. Waterguard contains $0.178 \mathrm{M}$ sodium hypochlorite $(\mathrm{NaOCl})$ as the disinfectant [30].

\section{Procedure of exposure of S. epidermidis biofilm and planktonic cells to the physico-chemical stresses commonly recommended for disinfection}

The effectiveness of the physico-chemical stress induced by the commonly recommended disinfectants against $S$. epidermidis biofilm and planktonic cells was determined as described in [16] with few modifications. Briefly, $1 \mathrm{~mL}$ of $S$. epidermidis biofilm or planktonic culture diluted to an $\mathrm{OD}_{600}$ of 1.0 was transferred to $9 \mathrm{~mL}$ of 1 . $72 \mathrm{M} \mathrm{NaCl}$ (Unilab Limited, Nairobi, Kenya), solution containing $150 \mu \mathrm{L}$ waterguard in $1 \mathrm{~L}$ of water (Supersleek, Nairobi, Kenya) or $1.77 \mathrm{M} \mathrm{H}_{2} \mathrm{O}_{2}$ (RFCL Limited, New Delhi, India) vortexed for 2 min then incubated at $37{ }^{\circ} \mathrm{C}$ with shaking at $120 \mathrm{rpm}$ for $60 \mathrm{~min}$. For heat stress, $1 \mathrm{~mL}$ of $S$. epidermidis biofilm or planktonic culture diluted to an $\mathrm{OD}_{600}$ of 1.0 was added to $9 \mathrm{~mL}$ of sterile distilled water and then placed in a water bath model JSWB-11(T) (JS Research Inc., Gongju-city, Korea) at $60{ }^{\circ} \mathrm{C}$. At 0,30 and $60 \mathrm{~min}$ of exposure to each disinfectant, $1 \mathrm{~mL}$ sample was drawn for colony-forming units (CFUs) enumeration. To neutralize the waterguard and $\mathrm{H}_{2} \mathrm{O}_{2}$-treated cultures, $2 \mathrm{~g} / \mathrm{L}$ sodium thiosulphate (Unilab Limited, Nairobi, Kenya) was placed in the first dilution tube. For $\mathrm{NaCl}$ stress-treated cultures, sterile distilled water was used instead of sodium thiosulphate. For heat stress, sterile water at $4{ }^{\circ} \mathrm{C}$ was placed in the first dilution tube to lower the temperature. Three replicate experiments were conducted.

\section{Enumeration and normalization of CFUs of S. epidermidis biofilm and planktonic cells exposed to the physico- chemical stresses commonly recommended for disinfection}

The S. epidermidis biofilm and planktonic cells sampled at 0,30 and 60 min were enumerated as described in [32] with few modifications. Briefly, $1 \mathrm{~mL}$ sample obtained at each time point $(0,30$ and $60 \mathrm{~min})$ was serially diluted 5fold. Then, $100 \mu \mathrm{L}$ of the $10^{-5}$ dilution was plated in duplicate on Nutrient agar (HiMedia Laboratories Pvt. Limited, Mumbai, India) and then incubated for $20 \mathrm{~h}$ at $37{ }^{\circ} \mathrm{C}$. The CFUs were counted using Colony Counter SC6 plus (Bibby Scientific Limited, Staffordshire, United Kingdom) and then converted into CFU/mL.
The CFU/mL values were normalized into log reduction of $\mathrm{CFU} / \mathrm{mL}$ as described in [16]. Briefly, log reduction is defined as the negative $\log _{10}$ of the quotient of $\mathrm{CFU}$ after treatment and before treatment $\left[-\log _{10}\right.$ (CFUafter treatment $\left.\left./ \mathrm{CFU}_{\text {before treatment }}\right)\right]$. The $\log$ reduction of $\mathrm{CFU} / \mathrm{mL}$ for three replicate experiments were averaged and standard error of the mean (SEM) calculated. A log reduction value is directly proportional to the difference between the number of CFUs after and before treatment.

\section{Quantification of the effects of sub-lethal physico- chemical stress exposure on eDNA release by $S$. epidermidis biofilm and planktonic cells}

It is recommended that bacterial biofilm samples exhibiting high resistance to disinfectants should be selected for further molecular analyses of the resistance mechanism(s) [33]. Therefore, a subset of S. epidermidis biofilm cultures $(n=12)$ that showed high resistance (smaller $\log$ reduction of $\mathrm{CFU} / \mathrm{mL}$ units) to physicochemical stress induced by the four commonly recommended disinfectants and the corresponding planktonic cultures were selected for eDNA experiments. Sub-lethal stress exposure induces bacterial eDNA release by partial repairable cell lysis or lysis-independent mechanisms and not via mass cell die off or explosive lysis [34] hence suitable for evaluating the effects of a stress agent on bacterial biofilm mechanisms such as eDNA release.

\section{Determination of the sub-lethal physico-chemical stress conditions}

Sub-lethal concentrations of $\mathrm{NaCl}, \mathrm{NaOCl}$, and $\mathrm{H}_{2} \mathrm{O}_{2}$ were determined as described in [35] with some modifications. Briefly, $200 \mu \mathrm{L}$ aliquot of S. epidermidis planktonic culture (pooled together from five different planktonic cultures) diluted to an $\mathrm{OD}_{600}$ of 1.0 was inoculated into $2 \mathrm{~mL}$ of increasing concentrations of $\mathrm{NaCl}$ (Unilab Limited, Nairobi, Kenya), $\mathrm{NaOCl}$ (Supersleek, Nairobi, Kenya) or $\mathrm{H}_{2} \mathrm{O}_{2}$ (RFCL Limited, New Delhi, India) for $60 \mathrm{~min}$. At the 60th $\mathrm{min}, 1 \mathrm{~mL}$ of $\mathrm{NaOCl}$ and $\mathrm{H}_{2} \mathrm{O}_{2}$ stress-treated $S$. epidermidis cultures were neutralized with $200 \mu \mathrm{L}$ of $2 \mathrm{~g} / \mathrm{L}$ sodium thiosulphate (Unilab Limited, Nairobi, Kenya) and then serially diluted 8-fold. A $100 \mu \mathrm{L}$ of the $10^{-8}$ dilution was plated in duplicate on Tryptic Soy Agar (Sigma Aldrich Chemie GmbH, Steinheim, Germany) at $37{ }^{\circ} \mathrm{C}$ for $18 \mathrm{~h}$. Then, CFUs were enumerated using Colony Counter SC6 plus (Bibby Scientific Limited, Staffordshire, United Kingdom). The following physico-chemical stress concentrations that induced stress without severe growth inhibition were used: $0.8 \mathrm{M} \mathrm{NaCl}, 5 \mathrm{mM} \mathrm{NaOCl}$ and $50 \mu \mathrm{M} \mathrm{H}_{2} \mathrm{O}_{2}$. For sublethal heat stress, $50{ }^{\circ} \mathrm{C}$ that has been shown to induce stress without degrading eDNA was used [36]. 
Procedure of exposure of S. epidermidis biofilm and planktonic cells to the sub-lethal physico-chemical stress conditions

The S. epidermidis biofilm and planktonic cells were challenged with the four sub-lethal physico-chemical stresses as described in [16] with slight modifications. Briefly, $200 \mu \mathrm{L}$ of $S$. epidermidis biofilm or planktonic culture diluted to an $\mathrm{OD}_{600}$ of 1.0 was inoculated into $400 \mu \mathrm{L}$ of TSB (Sigma Aldrich Chemie GmbH, Steinheim, Germany) supplemented with $700 \mu \mathrm{L}$ of $0.8 \mathrm{M}$ $\mathrm{NaCl}$ (Unilab Limited, Nairobi, Kenya), $5 \mathrm{mM} \mathrm{NaOCl}$

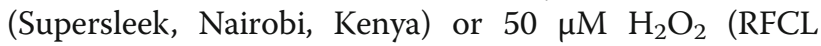
Limited, New Delhi, India), vortexed for $2 \mathrm{~min}$ and then incubated at $37{ }^{\circ} \mathrm{C}$ with shaking at $120 \mathrm{rpm}$ for $60 \mathrm{~min}$. At the 60th min, $\mathrm{NaOCl}$ and $\mathrm{H}_{2} \mathrm{O}_{2}$ stress-treated S. epidermidis biofilm and planktonic cultures were neutralized by adding $200 \mu \mathrm{L}$ of $2 \mathrm{~g} / \mathrm{L}$ sodium thiosulphate (Unilab Limited, Nairobi, Kenya) to the tubes. For S. epidermidis biofilm or planktonic cultures exposed to 0 . $8 \mathrm{M} \mathrm{NaCl}$, sterile distilled water was added instead of sodium thiosulphate. The untreated controls for $\mathrm{NaCl}$, $\mathrm{NaOCl}$ and $\mathrm{H}_{2} \mathrm{O}_{2}$ comprised of $200 \mu \mathrm{L}$ of S. epidermidis biofilm or planktonic culture inoculated into $400 \mu \mathrm{L}$ of TSB (Sigma Aldrich Chemie GmbH, Steinheim, Germany) supplemented with $700 \mu \mathrm{L}$ of sterile distilled water. For heat stress exposure, $200 \mu \mathrm{L}$ of $S$. epidermidis biofilm or planktonic culture was inoculated into $400 \mu \mathrm{L}$ of TSB (Sigma Aldrich Chemie $\mathrm{GmbH}$ ) supplemented with $700 \mu \mathrm{L}$ of sterile distilled water and then transferred to a water bath model JSWB-11(T) (JS Research Inc., Gongju-city, Korea) at $50{ }^{\circ} \mathrm{C}$ for $60 \mathrm{~min}$. At the 60 th $\min , 200 \mu \mathrm{L}$ of sterile distilled water at $4{ }^{\circ} \mathrm{C}$ was added to lower the temperature. The untreated control was $200 \mu \mathrm{L}$ of $S$. epidermidis biofilm or planktonic culture inoculated into $400 \mu \mathrm{L}$ of TSB (Sigma Aldrich Chemie $\mathrm{GmbH}$ ) supplemented with $700 \mu \mathrm{L}$ of sterile distilled water then transferred to water bath model JSWB-11(T) (JS Research Inc., Gongju-city, Korea) at $25{ }^{\circ} \mathrm{C}$ for $60 \mathrm{~min}$.

\section{Isolation of eDNA}

To minimize variations associated with DNA precipitation, eDNA was obtained directly from the supernatant [37]. The exopolymeric substances were separated from bacterial cells by high-speed centrifugation which does not cause cell lysis [38]. Free and bound eDNA were then obtained from the exopolymeric substances using Tris-Ethylenediaminetetraacetic acid (EDTA) (TE) buffer [39, 40].

The eDNA released by the sub-lethal stress-treated $S$. epidermidis biofilm and planktonic cultures and their respective untreated controls was obtained as described in [20] with few modifications. Briefly, sub-lethal physicochemical stress-treated culture or untreated control was centrifuged at $20,000 \mathrm{rpm}$ at $4{ }^{\circ} \mathrm{C}$ for $20 \mathrm{~min}$. Then, $1 \mathrm{~mL}$ of the supernatant was pipetted into $1 \mathrm{~mL}$ of TE buffer (10 mM Tris, $1 \mathrm{mM}$ EDTA, $\mathrm{pH}$ 8.0) and then centrifuged at $13,000 \mathrm{rpm}$ for $3 \mathrm{~min}$. Finally, $30 \mu \mathrm{L}$ of the supernatant was suspended in $100 \mu \mathrm{L}$ of TE buffer and then stored at $-20{ }^{\circ} \mathrm{C}$ until further use.

\section{Quantification of eDNA}

The eDNA in the supernatant was quantified using Qubit $^{\mathrm{TM}}$ dsDNA high sensitivity (HS) assay kit (Invitrogen, Paisley, United Kingdom) and Qubit ${ }^{\odot}$ 2.0 Fluorometer (Life Technologies, Carlsbad, USA) following the manufacturers' instructions. Briefly, Qubit working solution was prepared by diluting $1 \mu \mathrm{L}$ of Qubit ${ }^{\mathrm{Tm}}$ dsDNA HS reagent (Molecular Probes Inc., Willow Creek Road Eugene, Oregon) with $199 \mu \mathrm{L}$ of Qubit ${ }^{\mathrm{Tm}}$ dsDNA HS buffer (Invitrogen, Paisley, United Kingdom) in a plastic tube. Then, $2 \mu \mathrm{L}$ of the supernatant was added to $198 \mu \mathrm{L}$ of the working solution in a plastic tube, vortexed for $3 \mathrm{~s}$ and then incubated at room temperature for $2 \mathrm{~min}$. The tube was loaded into a Qubit ${ }^{\oplus}$ 2.0 Fluorometer (Life Technologies, Carlsbad, USA) to quantify eDNA in $\mathrm{ng} / \mu \mathrm{L}$. The experiments were performed in duplicate. Percentage change in eDNA yield expressed as $\left[\left\{\mathrm{eDNA}_{\text {stress treated cells }}-\mathrm{eDNA}_{\text {untreated con- }}\right.\right.$ trols) / $\left.\mathrm{eDNA}_{\text {untreated controls }}\right\} \times 100 \%$ ] was computed for pairs of S. epidermidis biofilm and planktonic cultures.

\section{Data analyses}

Data obtained were stored in Microsoft Office Excel and analyzed using Prism 5 for windows version 5.03 (GraphPad software, Inc., California, USA). Data normality was verified using Shapiro-Wilk test. Normally and non-normally distributed data were presented as mean $( \pm$ SEM) and median (25th and 75th percentiles) respectively. Differences in log reduction of $\mathrm{CFU} / \mathrm{mL}$ between $S$. epidermidis biofilm and planktonic cells subjected to each of the four commonly recommended physico-chemical disinfectants were compared by paired $t$-test. Comparisons of log reductions of CFU/mL of $S$. epidermidis biofilm or planktonic cells among the four commonly recommended physico-chemical disinfectants were performed using repeated measures analysis of variance (ANOVA) with Tukey's post hoc. Differences in eDNA release between $S$. epidermidis biofilm and planktonic cells treated with each of the four sub-lethal physicochemical stresses were conducted by Wilcoxon matched-pairs signed rank test. Similarly, differences in eDNA yield between sub-lethal physico-chemical stress-treated $S$. epidermidis biofilm or planktonic cells and their respective untreated controls were analyzed by Wilcoxon matched-pairs signed rank test. Statistical significance was considered at $p<0.05$. 


\section{Results}

Susceptibility patterns of $S$. epidermidis biofilm and planktonic cells to physico-chemical stress induced by the commonly recommended disinfectants

One of the specific aims of the present study was to determine the susceptibility patterns of $S$. epidermidis biofilm and planktonic cells to physico-chemical stress induced by the four commonly recommended disinfectants (heat, $\mathrm{NaCl}, \mathrm{NaOCl}$ and $\mathrm{H}_{2} \mathrm{O}_{2}$ ) in domestic and human healthcare settings.

\section{S. epidermidis planktonic cells are more susceptible to heat stress than the biofilm cells}

The $S$. epidermidis biofilms exposed to heat $\left(60{ }^{\circ} \mathrm{C}\right)$ stress for $30 \mathrm{~min}$ exhibited a significantly lower log reduction of $\mathrm{CFU} / \mathrm{mL}$ than the corresponding planktonic cells $(p<0.0001)$ (Fig. 1a). Similarly, the log reduction of $\mathrm{CFU} / \mathrm{mL}$ of $S$. epidermidis biofilms subjected to the same stress for $60 \mathrm{~min}$ was statistically lower than the planktonic cells $(p<0.0001)$ (Fig. 1a). These results indicated that $60{ }^{\circ} \mathrm{C}$ was less effective against $S$. epidermidis biofilms compared to the corresponding planktonic cells. Further analyses showed that $S$. epidermidis biofilm or planktonic cells subjected to $60{ }^{\circ} \mathrm{C}$ stress for $30 \mathrm{~min}$ had a significantly lower log reduction of CFU/mL compared to their respective cells exposed to $60{ }^{\circ} \mathrm{C}$ stress for 60 min $(p<0.0001)$ (Table 1). This indicated that the $S$. epidermidis biofilm or planktonic cells killing by the heat stress were directly proportional to the exposure duration.

\section{S. epidermidis biofilms are less susceptible to $\mathrm{NaCl}$ stress than the planktonic cells}

When challenged with $1.72 \mathrm{M} \mathrm{NaCl}$ for $30 \mathrm{~min}, S$. epidermidis biofilms exhibited a significantly lower $\log$ reduction of $\mathrm{CFU} / \mathrm{mL}$ than the analogous planktonic cells $(p<0.0001)$ (Fig. 1b). Treatment of S. epidermidis biofilm and planktonic cells with $1.72 \mathrm{M}$ $\mathrm{NaCl}$ for 60 min yielded a similar pattern $(p<0$. 0001) (Fig. 1b). These results showed that $1.72 \mathrm{M}$ $\mathrm{NaCl}$ was less effective against $S$. epidermidis biofilms than the corresponding planktonic cells. Further analyses revealed that $S$. epidermidis biofilm or planktonic cells subjected to $1.72 \mathrm{M} \mathrm{NaCl}$ stress for $30 \mathrm{~min}$ had a significantly lower log reduction of $\mathrm{CFU} / \mathrm{mL}$ than their respective cells exposed to 1 . $72 \mathrm{M} \mathrm{NaCl}$ stress for $60 \mathrm{~min}(p<0.0001)$ (Table 1$)$. These implied that the effectiveness of $1.72 \mathrm{M} \mathrm{NaCl}$ on $S$. epidermidis biofilm or planktonic cells is dependent on the exposure duration.

\section{$\mathrm{NaOCl}$ stress is more effective against $\mathrm{S}$. epidermidis planktonic than biofilm cells}

S. epidermidis biofilms exhibited significantly lower log reduction of $\mathrm{CFU} / \mathrm{mL}$ when exposed to a solution containing $150 \mu \mathrm{L}$ of waterguard in $1 \mathrm{~L}$ of water for $30 \mathrm{~min}$ a

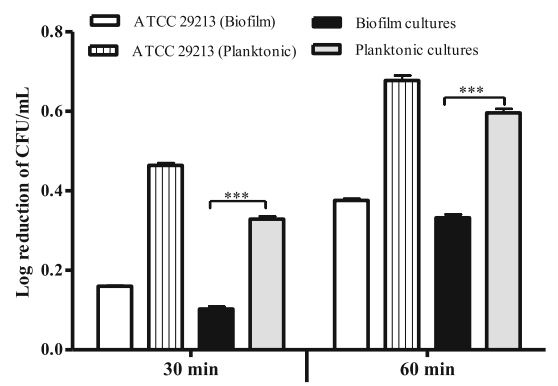

C

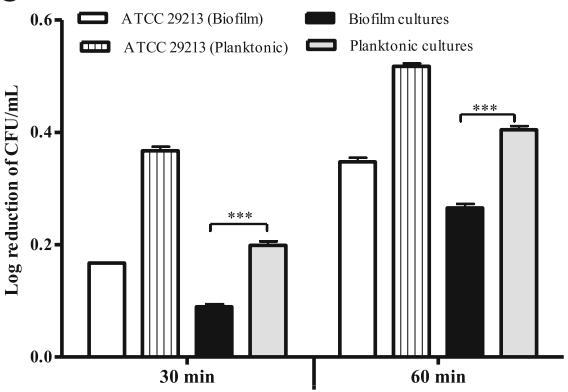

b

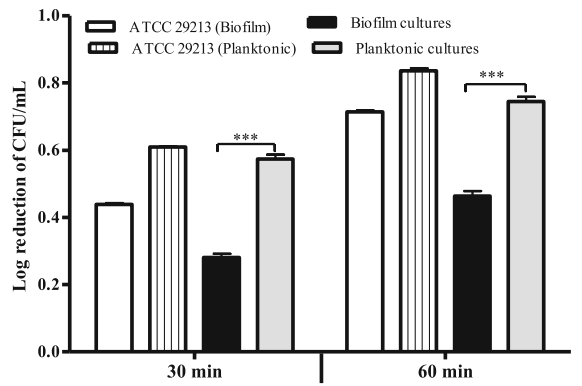

d

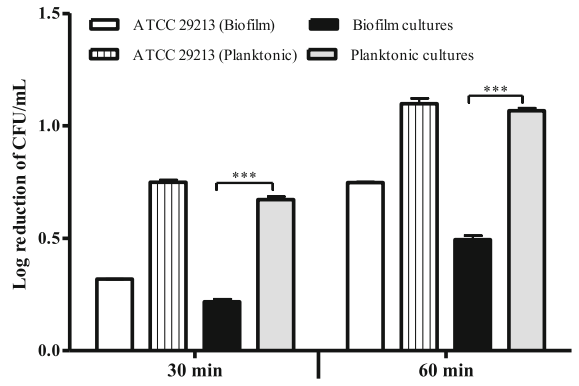

Fig. 1 Susceptibility patterns of S. epidermidis biofilm and planktonic cells to physico-chemical stress exposure. The log reduction of CFU/mL of pairs of S. epidermidis biofilm and planktonic cultures challenged with $60^{\circ} \mathrm{C}(\mathbf{a}), 1.72 \mathrm{M} \mathrm{NaCl}(\mathbf{b})$, a solution containing $150 \mu \mathrm{L}$ of waterguard in $1 \mathrm{~L}$ of water (c) and $1.77 \mathrm{M} \mathrm{H}_{2} \mathrm{O}_{2}$ (d) for 30 and 60 min. Value for ATCC 29213 represents the mean for three independent experiments. Error bars depict SEM. Statistical significance between S. epidermidis biofilm and planktonic cultures were determined using paired t-test $\left(*^{* *}, p<0.0001\right)$ 
Table 1 Effectiveness of physico-chemical stress exposure durations on S. epidermidis biofilm and planktonic cells

\begin{tabular}{|c|c|c|c|c|}
\hline \multirow{2}{*}{$\begin{array}{l}\text { Type of } \\
\text { culture }\end{array}$} & \multicolumn{4}{|c|}{ Mean \pm SEM of log reduction of CFU/mL of cells exposed to commonly recommended stresses } \\
\hline & Heat & $\mathrm{NaCl}$ & $\mathrm{NaOCl}$ & $\mathrm{H}_{2} \mathrm{O}_{2}$ \\
\hline \multicolumn{5}{|l|}{ Biofilm } \\
\hline $30 \mathrm{~min}$ & $0.110 \pm 0.006$ & $0.281 \pm 0.011$ & $0.089 \pm 0.005$ & $0.219 \pm 0.011$ \\
\hline \multirow[t]{2}{*}{$60 \mathrm{~min}$} & $0.332 \pm 0.009$ & $0.464 \pm 0.014$ & $0.266 \pm 0.007$ & $0.494 \pm 0.018$ \\
\hline & $p<0.05$ & $p<0.05$ & $p<0.05$ & $p<0.05$ \\
\hline \multicolumn{5}{|l|}{ Planktonic } \\
\hline $30 \mathrm{~min}$ & $0.342 \pm 0.007$ & $0.574 \pm 0.013$ & $0.199 \pm 0.007$ & $0.673 \pm 0.013$ \\
\hline \multirow[t]{2}{*}{$60 \mathrm{~min}$} & $0.596 \pm 0.010$ & $0.744 \pm 0.015$ & $0.404 \pm 0.007$ & $1.067 \pm 0.013$ \\
\hline & $p<0.05$ & $p<0.05$ & $p<0.05$ & $p<0.05$ \\
\hline
\end{tabular}

S. epidermidis biofilm and planktonic cultures were exposed to $60{ }^{\circ} \mathrm{C}, 1.72 \mathrm{M} \mathrm{NaCl}$, a solution containing $150 \mu \mathrm{L}$ of waterguard in $1 \mathrm{~L}$ of water and $1.77 \mathrm{M} \mathrm{H} \mathrm{O}_{2}$ for 30 and $60 \mathrm{~min}$. Statistical significance between 30 and 60 min physico-chemical stress exposure durations on $\mathrm{S}$. epidermidis biofilm or planktonic cultures was determined by paired $t$-test

than the analogous planktonic cells $(p<0.0001)$ (Fig. 1c). A similar pattern was observed upon exposure of S. epidermidis biofilm and planktonic cells to a solution containing $150 \mu \mathrm{L}$ waterguard in $1 \mathrm{~L}$ of water for $60 \mathrm{~min}(p<0.0001)$ (Fig. 1c). These results indicated that $S$. epidermidis biofilms were more protected against a solution containing $150 \mu \mathrm{L}$ of waterguard in $1 \mathrm{~L}$ of water than the corresponding planktonic cells. Further analyses showed that S. epidermidis biofilm or planktonic cells subjected to a solution containing $150 \mu \mathrm{L}$ of waterguard in $1 \mathrm{~L}$ of water for $30 \mathrm{~min}$ had a significantly lower log reduction of $\mathrm{CFU} / \mathrm{mL}$ than their respective cells exposed to the same stress for $60 \mathrm{~min}(p<0.0001)$ (Table 1). These results implied that the effectiveness of $\mathrm{NaOCl}$ stress against $S$. epidermidis biofilm and planktonic cells was proportional to the exposure duration.

\section{$\mathrm{H}_{2} \mathrm{O}_{2}$ stress is less effective against $\mathrm{S}$. epidermidis biofilms} than planktonic cells

S. epidermidis biofilms treated with $1.77 \mathrm{M} \mathrm{H}_{2} \mathrm{O}_{2}$ for $30 \mathrm{~min}$ had a statistically lower log reduction of CFU/ $\mathrm{mL}$ than the analogous planktonic cells $(p<0.0001)$ (Fig. 1d). Similarly, S. epidermidis biofilms challenged with 1 . $77 \mathrm{M} \mathrm{H}_{2} \mathrm{O}_{2}$ for 60 min showed a significantly lower log reduction than the corresponding planktonic cells ( $p$ $<0.0001$ ) (Fig. 1d). These results indicated that 1 . $77 \mathrm{M} \mathrm{H}_{2} \mathrm{O}_{2}$ stress is more effective against S. epidermidis planktonic cells than the corresponding biofilm cells. Further, S. epidermidis biofilm or planktonic cells challenged with $1.77 \quad \mathrm{M} \mathrm{H}_{2} \mathrm{O}_{2}$ for $30 \mathrm{~min}$ showed a significantly lower log reduction of CFU/ $\mathrm{mL}$ than their respective cells subjected to the same stress for $60 \mathrm{~min}(p<0.0001)$ (Table 1$)$. This implied that the efficacy of $1.77 \mathrm{M} \mathrm{H}_{2} \mathrm{O}_{2}$ against S. epidermidis biofilm and planktonic cells was directly proportional to the exposure duration.

\section{Comparison of the effectiveness of physico-chemical} stress induced by the commonly recommended disinfectants against $S$. epidermidis biofilm and planktonic cells

The present study also compared the effectiveness of physico-chemical stress induced by the four commonly recommended disinfectants against S. epidermidis biofilm or planktonic cells. Repeated measures ANOVA showed that the log reductions of CFU $/ \mathrm{mL}$ of S. epidermidis biofilm cells differed significantly among the four commonly recommended disinfectants upon exposure for 30 or $60 \mathrm{~min}(p<0.0001)$. Tukey's post hoc revealed that when $S$. epidermidis biofilm cells are exposed to the four commonly recommended disinfectants for $30 \mathrm{~min}$, the $\log$ reduction of $\mathrm{CFU} / \mathrm{mL}$ was significantly highest for $1.72 \mathrm{M} \mathrm{NaCl}$ followed by $1.77 \mathrm{M} \mathrm{H}_{2} \mathrm{O}_{2}, 60{ }^{\circ} \mathrm{C}$ and a solution containing $150 \mu \mathrm{L}$ of waterguard in $1 \mathrm{~L}$ of water in that order (Fig. 2a). Conversely, when S. epidermidis biofilms were subjected to the four commonly recommended disinfectants for $60 \mathrm{~min}$, Tukey's post hoc showed that the $\log$ reduction of $\mathrm{CFU} / \mathrm{mL}$ was significantly highest for $1.77 \mathrm{M} \mathrm{H}_{2} \mathrm{O}_{2}$, followed by $1.72 \mathrm{M}$ $\mathrm{NaCl}, 60{ }^{\circ} \mathrm{C}$ and a solution containing $150 \mu \mathrm{L}$ of waterguard in $1 \mathrm{~L}$ of water in that order (Fig. 2a). These results indicated that susceptibilities of $S$. epidermidis biofilm cells to physico-chemical stress induced by the four commonly recommended disinfectants for $30 \mathrm{~min}$ was not dependent on the diffusion rate (molecular weight) $\left(\mathrm{NaCl}>\mathrm{H}_{2} \mathrm{O}_{2}>\right.$ heat $\left.>\mathrm{NaOCl}\right)$. However, susceptibility of $S$. epidermidis biofilm cells to physicochemical stress induced by the four commonly recommended disinfectants for $60 \mathrm{~min}$ was dependent on the diffusion rate of the disinfectants $\left(\mathrm{H}_{2} \mathrm{O}_{2}>\right.$ $\mathrm{NaCl}>$ heat $>\mathrm{NaOCl}$.

Furthermore, repeated measures ANOVA revealed that the $\log$ reductions of $\mathrm{CFU} / \mathrm{mL}$ of $S$. epidermidis planktonic cells differed significantly among the four 

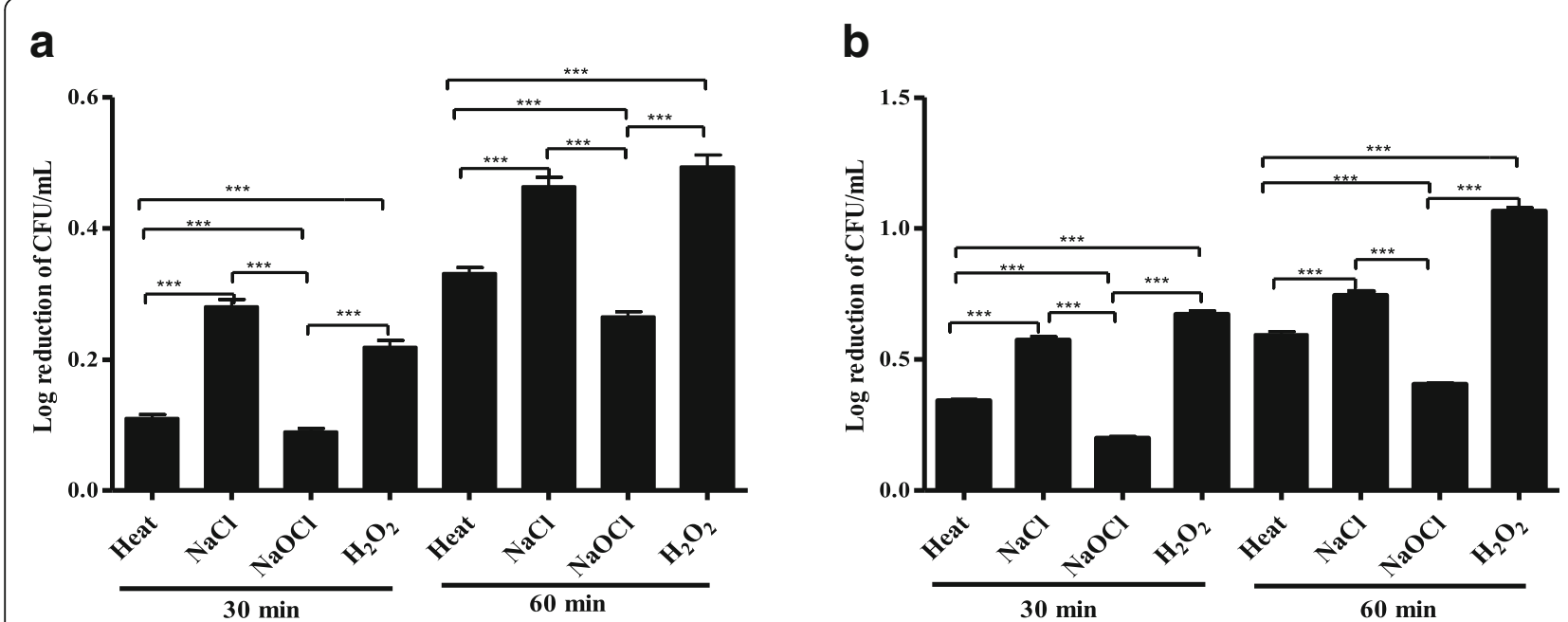

Fig. 2 Comparison of the effectiveness of physico-chemical stresses against $S$. epidermidis biofilm and planktonic cells. The log reduction of CFU/ $\mathrm{mL}$ of pairs of S. epidermidis biofilm (a) and planktonic (b) cultures subjected to $60{ }^{\circ} \mathrm{C}, 1.72 \mathrm{M} \mathrm{NaCl}$, a solution containing $150 \mu \mathrm{L}$ of waterguard in $1 \mathrm{~L}$ of water and $1.77 \mathrm{M} \mathrm{H}_{2} \mathrm{O}_{2}$ for 30 and 60 min. Error bars represent SEM. Statistical significance was determined using repeated measures ANOVA with Tukey's post hoc $\left(^{* *}, p<0.0001\right)$

commonly recommended disinfectants upon exposure for 30 or $60 \mathrm{~min}(p<0.0001)$. Tukey's post hoc showed that the $\log$ reduction of $\mathrm{CFU} / \mathrm{mL}$ of $S$. epidermidis planktonic cells were significantly highest for $1.77 \mathrm{M}$ $\mathrm{H}_{2} \mathrm{O}_{2}$, followed by $1.72 \mathrm{M} \mathrm{NaCl}, 60{ }^{\circ} \mathrm{C}$ and a solution containing $150 \mu \mathrm{L}$ of waterguard in $1 \mathrm{~L}$ of water in that order at both 30 and $60 \mathrm{~min}$ of exposure $\left(\mathrm{H}_{2} \mathrm{O}_{2}>\mathrm{NaCl}>\right.$ heat $\left.>\mathrm{NaOCl}\right)$ (Fig. 2b). These results implied that the susceptibilities of $S$. epidermidis planktonic cells to the four commonly recommended disinfectants for 30 or $60 \mathrm{~min}$ were dependent on the diffusion rate of the disinfectants.

Effects of sub-lethal physico-chemical stress exposure on eDNA release by $S$. epidermidis biofilm and planktonic cells

To effectively control, manage and eradicate bacterial biofilms in domestic and healthcare settings it is necessary to understand the mechanisms that mediate their survival against commonly reccommded physico-chemical disinfectants. Consequently, a second specific aim of the present study was to evaluate the eDNA release as a potential mechanism that underlies S. epidermidis biofilms resistance to physico-chemical stress exposure.

\section{Effect of heat stress on eDNA release by S. epidermidis biofilm and planktonic cells}

The percentage change in eDNA yield by $50{ }^{\circ} \mathrm{C}$-treated S. epidermidis biofilms was slightly more than the corresponding planktonic cells albeit not statistically different $(p=0.4697)$ (Fig. 3a). Further analysis showed that $50^{\circ}$ C-treated S. epidermidis biofilm cells released significantly increased eDNA than the respective untreated controls $(p=0.0098)$ (Table 2). On the contrary, $50{ }^{\circ} \mathrm{C}$ treated planktonic cells yielded more eDNA than the untreated controls but the difference was not statistically significant $(p=0.7910)$ (Table 2).

\section{Impact of $\mathrm{NaCl}$ stress on eDNA release by S. epidermidis biofilm and planktonic cells}

S. epidermidis planktonic cells exposed to $0.8 \mathrm{M} \mathrm{NaCl}$ stimulated higher percentage change in eDNA yield than the analogous biofilm cells although the difference was not statistically significant ( $p=0.8501)$ (Fig. 3b). Further analysis showed that $0.8 \mathrm{M} \mathrm{NaCl}$-treated $S$. epidermidis biofilm cells released less eDNA than the untreated controls although not statistically different $(p=0.3804)$ (Table 2). However, $0.8 \mathrm{M} \mathrm{NaCl}$-treated S. epidermidis planktonic cells yielded more eDNA than the untreated controls but the difference was not statistically significant $(p=0.6772)$ (Table 2). These results showed that osmotic stress does not significantly affect eDNA release by S. epidermidis biofilm and planktonic cells.

Effects of oxidative stresses on eDNA release by $S$. epidermidis biofilm and planktonic cells

Significantly increased percentage change in eDNA was released by $S$. epidermidis biofilms exposed to $5 \mathrm{mM}$ $\mathrm{NaOCl}$ compared to the corresponding planktonic cells $(p=0.0015)$ (Fig. 3c). Further analysis showed that $5 \mathrm{mM}$ $\mathrm{NaOCl}$-treated S. epidermidis biofilm cells released significantly more eDNA than the untreated controls $(p=0$. 0005) (Table 2). On the contrary, $5 \mathrm{mM} \mathrm{NaOCl}$-treated $S$. epidermidis planktonic cells produced slightly more eDNA than the untreated controls but the difference was not significant $(p=0.9097)$ (Table 2). 
a

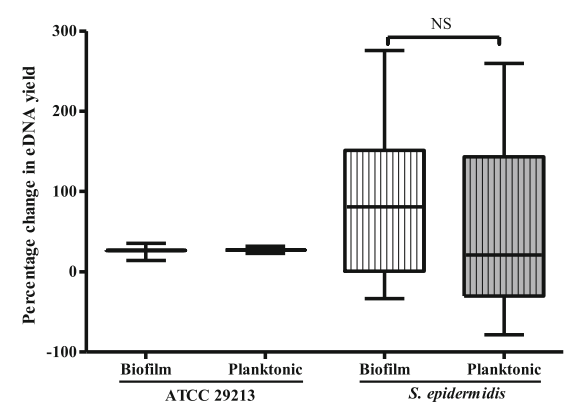

C

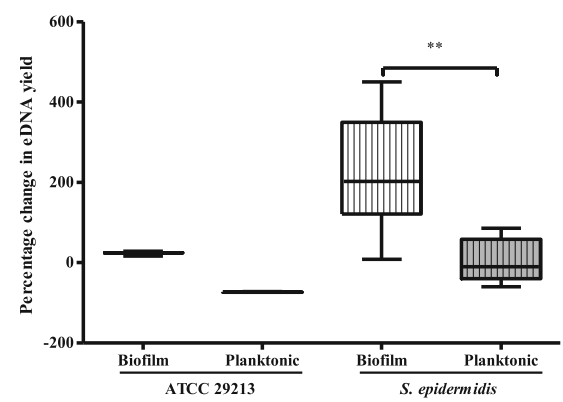

b

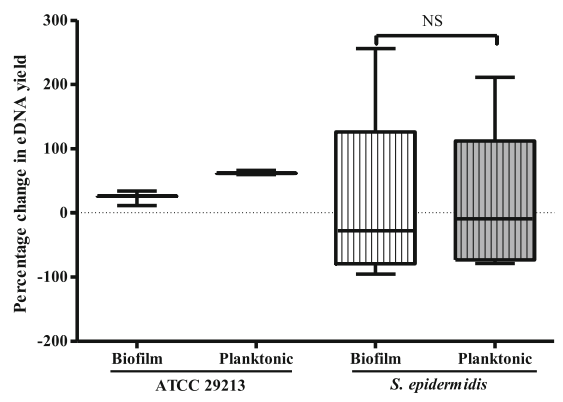

d

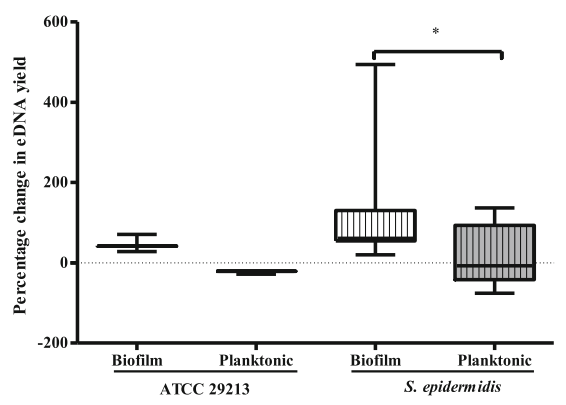

Fig. 3 Impacts of physico-chemical stress exposure on eDNA release by S. epidermidis biofilm and planktonic cells. The percentage change in eDNA yield by pairs of $\mathrm{S}$. epidermidis biofilm and planktonic cultures exposed to sub-lethal heat $\left(50^{\circ} \mathrm{C}\right)(\mathbf{a}), 0.8 \mathrm{M} \mathrm{NaCl}(\mathbf{b}), 5 \mathrm{mM} \mathrm{NaOCl}(\mathbf{c})$ and $50 \mathrm{MM} \mathrm{H}_{2} \mathrm{O}_{2}$ (d) for $60 \mathrm{~min}$. The horizontal line across the box is the median percentage change in eDNA yield, the lower and upper ends of the box are the 25th and 75th percentiles. The whiskers represent the minimum and maximum percentage changes in eDNA yield. Values for ATCC 29213 are for three independent experiments. Statistical significance between S. epidermidis biofilm and planktonic cultures were determined by Wilcoxon matched-pairs signed rank test ( ${ }^{\mathrm{NS}}, p>0.05 ;{ }^{*}, p<0.05 ;{ }^{* *}, p<0.01$ )

When challenged with $50 \mu \mathrm{M} \mathrm{H} \mathrm{H}_{2} \mathrm{O}_{2}$ stress for 60 min, the $S$. epidermidis biofilm cells exhibited significantly increased percentage change in eDNA than the analogous planktonic cells $(p=0.0210)$ (Fig. 3d). Further analyses revealed that $50 \mu \mathrm{M} \mathrm{H}_{2} \mathrm{O}_{2}$-treated S. epidermidis biofilm cells produced significantly more eDNA than the untreated controls $(p=0.0005)$ (Table 2). In contrast, the eDNA yield between $50 \mu \mathrm{M} \mathrm{H}_{2} \mathrm{O}_{2}$-treated S. epidermidis planktonic cells and the respective untreated controls was not significantly different $(p=0.7910)$ (Table 2). Taken together, these results indicated that $S$. epidermidis biofilm cells enhance eDNA release in response to $5 \mathrm{mM} \mathrm{NaOCl}$ and $50 \mu \mathrm{M} \mathrm{H} \mathrm{H}_{2} \mathrm{O}_{2}$ stress exposure.

\section{Discussion}

Susceptibility patterns of S. epidermidis biofilm and planktonic cells to physico-chemical stress induced by the commonly recommended disinfectants

Bacterial biofilms are most frequently encountered in domestic and healthcare environments [41, 42]. Thus,

Table 2 Impacts of sub-lethal physico-chemical stresses on eDNA release by S. epidermidis biofilm and planktonic cells

\begin{tabular}{|c|c|c|c|c|}
\hline \multirow[t]{2}{*}{ Type of culture } & \multicolumn{4}{|c|}{ Mean \pm SEM of eDNA yield in $\mathrm{ng} / \mathrm{\mu L}$ by cells exposed to sub-lethal stresses } \\
\hline & Heat & $\mathrm{NaCl}$ & $\mathrm{NaOCl}$ & $\mathrm{H}_{2} \mathrm{O}_{2}$ \\
\hline \multicolumn{5}{|l|}{ Biofilm } \\
\hline Untreated controls & $0.110 \pm 0.019$ & $0.482 \pm 0.159$ & $0.089 \pm 0.021$ & $0.231 \pm 0.056$ \\
\hline \multirow[t]{2}{*}{ Treated cells } & $0.221 \pm 0.058$ & $0.285 \pm 0.095$ & $0.292 \pm 0.072$ & $0.451 \pm 0.095$ \\
\hline & $p=0.0098$ & $p=0.3271$ & $p=0.0005$ & $p=0.0005$ \\
\hline \multicolumn{5}{|l|}{ Planktonic } \\
\hline Untreated controls & $0.405 \pm 0.101$ & $0.242 \pm 0.067$ & $0.526 \pm 0.128$ & $0.137 \pm 0.031$ \\
\hline \multirow[t]{2}{*}{ Treated cells } & $0.394 \pm 0.071$ & $0.219 \pm 0.089$ & $0.536 \pm 0.123$ & $0.112 \pm 0.015$ \\
\hline & $p=0.7910$ & $p=0.6772$ & $p=0.9097$ & $p=0.7910$ \\
\hline
\end{tabular}

S. epidermidis biofilm and planktonic cultures were subjected to heat $\left(25\right.$ and $\left.50{ }^{\circ} \mathrm{C}\right), \mathrm{NaCl}(0$ and $0.8 \mathrm{M}), \mathrm{NaOCl}(0$ and $5 \mathrm{mM})$ and $\mathrm{H}_{2} \mathrm{O}_{2}(0$ and $50 \mu \mathrm{M})$ for $60 \mathrm{~min}$. Italics indicate statistical significance $(p<0.05)$ between stress treated cultures and the untreated controls as determined by Wilcoxon matched-pairs signed rank test 
prevention of acquisition, spread and establishment of biofilm-forming bacteria such as $S$. epidermidis using effective disinfection guidelines [12] in these environments is necessary. Therefore, the present study evaluated the effectiveness of four commonly recommended physico-chemical disinfectants against $S$. epidermidis biofilm and planktonic cells.

The present study showed that the commonly recommended heat stress was less effective against S. epidermidis biofilms compared to the corresponding planktonic forms. The present findings are in agreement with previous reports on different bacterial species such as $M$. bovis [9], S. enterica [11] and a fungus, Cryptococcus neoformans [43]. However, the previous studies reported on different bacterial species such as $M$. bovis which are cell wall-less, S. enterica that overproduce protective cellulosic polymer and a fungal biofilm hence may not inform bacterial biofilm response to heat stress. The observed increased heat stress resistance of S. epidermidis biofilms compared to the corresponding planktonic cells could probably be explained in two ways. First, since bacterial biofilms overexpress heat stress-related genes [44] resulting in heat shock proteins that consume excess energy in form of adenosine triphosphate [45], it is likely that the $S$. epidermidis biofilm cells overexpressed heat stress-related genes to protect them against the deleterious effects of heat stress. Second, an increase in temperature has been shown to switch the staphylococcal biofilm cells fatty acid profile such that the anteiso-C19 fatty acids known to have high melting point rises, leading to decreased membrane fluidity resulting in increased resistance to heat stress [32].

Furthermore, the present study showed that biofilm forms of S. epidermidis are more resistant to the commonly recommended $\mathrm{NaCl}$ stress than the analogous planktonic cells which is consistent with a previous report on $V$. cholerae $\mathrm{O} 1$ by Wai et al. [10]. However, the previous study used $V$. cholerae a bacterium highly adapted to high salinity [46] and utilized high salt concentration $(2.5 \mathrm{M} \mathrm{NaCl})$ that may not inform routine bacterial biofilm disinfection. The observed increased resistance of S. epidermidis biofilm cells to osmotic stress could possibly be due to the osmotic stress-enhanced production of exopolysaccharides and proteins that formed a water-retaining layer around S. epidermidis biofilm cells thus protecting the cells against dehydration $[23,47]$. An alternative explanation could be linked to the previous observation that osmotic stress enhances quorum sensing in bacterial biofilms [48] which correspondingly increases resistance against osmotic stress [49] by the $S$. epidermidis biofilm cells.

The present study also showed that the commonly recommended $\mathrm{NaOCl}$ stress is less effective against $S$. epidermidis biofilms compared to the analogous planktonic cells. The present finding is in consonance with several previous reports on different bacterial species that were either overproducing protective pellicles [11], were subjected to high [13] or low $\mathrm{NaOCl}$ concentrations [12], were overgrown for six days [16] or had protective mycolic acid rich membranes [15]. Thus, the previous reports may not inform general bacterial biofilm response to $\mathrm{NaOCl}$ stress. The observed increased S. epidermidis biofilm resistance could partly be due to the reaction of $\mathrm{NaOCl}$ with the ECM components such as proteins and polysaccharides and/or the slow diffusion across ECM barrier thus reducing the effect of $\mathrm{NaOCl}$ on most S. epidermidis biofilm cells [16].

The present study also demonstrated that $S$. epidermidis biofilms are more protected against the commonly recommended $\mathrm{H}_{2} \mathrm{O}_{2}$ stress than the analogous planktonic cells. The present finding concurs with previous reports on S. epidermidis [50], $V$. cholerae [10] and $B$. cenocepacia [12] exposed to low concentrations of $\mathrm{H}_{2} \mathrm{O}_{2}$ that are not routinely used for disinfection. In addition, Glynn et al. [50] reported on the effect of $\mathrm{H}_{2} \mathrm{O}_{2}$ on $S$. epidermidis biofilm formation using a semiquantitative approach which may not present a clear picture of $S$. epidermidis biofilms response to $\mathrm{H}_{2} \mathrm{O}_{2}$ stress. The observed increased resistance of $S$. epidermidis biofilms could possibly be attributed to neutralization of $\mathrm{H}_{2} \mathrm{O}_{2}$ by the ECM components such as polysaccharides and proteins and/or overexpression of catalase-producing genes resulting in overproduction of catalase enzymes that decompose the $\mathrm{H}_{2} \mathrm{O}_{2}$ [12] thereby reducing its effects on most of the inner $S$. epidermidis biofilm cells.

Taken together, the results presented in the present study showed that the susceptibility of $S$. epidermidis biofilm and planktonic cells was proportional to the duration of exposure to each of the four commonly recommended disinfectants. Generally, a disinfectant producing a $\log$ reduction unit above three $(99.9 \%$ bacterial reduction) is considered effective against a bacterial biofilm [33]. However, in the present study, S. epidermidis biofilm cells exhibited $\log$ reduction units below three $(<3)$ when subjected to the four commonly recommended disinfectants. This implied that the four physico-chemical stresses commonly recommended for disinfection in domestic and human healthcare settings were ineffective against the $S$. epidermidis biofilm cells hence creating a healthcare concern.

\section{Reaction-diffusion inhibition mechanism inadequately explains the increased $S$. epidermidis biofilms resistance to physico-chemical stresses commonly recommended for disinfection}

Bacterial biofilm resistance to osmotic and oxidative stress exposure is mostly attributed to the stress agent's reaction with and/or slow diffusion across the ECM 
(reaction-diffusion inhibition mechanism) $[16,51]$. The movement of the stress agents probably occur via waterfilled channels on the bacterial biofilm's ECM [2]. The observation that the susceptibility of S. epidermidis biofilm cells to the commonly recommended disinfectants for 60 min depended on the diffusion rate (molecular weight) $\left(\mathrm{H}_{2} \mathrm{O}_{2}>\mathrm{NaCl}>\right.$ heat $\left.>\mathrm{NaOCl}\right)$ appear to support the reaction-diffusion inhibition mechanism. It has been shown that $\mathrm{NaOCl}$ (with slowest diffusion rate) diffuses across the ECM in about $50 \mathrm{~min}$ [16]. Accordingly, all the four disinfectants should have crossed the ECM within the $60 \mathrm{~min}$ of exposure and killed an equal number of $S$. epidermidis biofilm and planktonic cells. Taking into account the observation that more S. epidermidis planktonic cells were killed compared to the corresponding biofilm cells at $60 \mathrm{~min}$ of exposure and that susceptibilities of the biofilm cells to the commonly recommended disinfectants for $30 \mathrm{~min}$ did not correspond to the diffusion rate, it is reasonable to surmise that the reaction-diffusion inhibition mechanism inadequately explains the increased resistance of $S$. epidermidis biofilm cells to the physicochemical stress induced by the commonly recommended disinfectants. This lends credence to the existence of complementary mechanism(s) of resistance against physicochemical stress exposure in S. epidermidis biofilms such as eDNA release [19] and upregulation of biofilm-specific stress resistance genes [3].

\section{Role of eDNA in S. epidermidis biofilms resistance to physico-chemical stress exposure}

The reaction-diffusion inhibition mechanism did not fully account for the increased S. epidermidis biofilms resistance to physico-chemical stress induced by the commonly recommended disinfectants relative to the planktonic forms. In the recent years, some studies have linked eDNA release with survival of bacterial [20-22] and fungal biofilms [23] against antibiotics and $\mathrm{H}_{2} \mathrm{O}_{2}$ respectively. Thus, the present study evaluated eDNA release as a potential complementary mechanism underlying S. epidermidis biofilms resistance to physico-chemical exposure.

The present study did not reveal any significant difference in eDNA release between the S. epidermidis biofilm and planktonic forms exposed to sub-lethal heat stress. However, the present study showed that the sub-lethal heat stress-treated S. epidermidis biofilms significantly enhanced eDNA release than the untreated controls. For $S$. epidermidis planktonic cells, no difference was observed in eDNA release between the treated cells and untreated controls. This set of results can be interpreted in two ways. On the one hand, the finding that eDNA released by $S$. epidermidis biofilm and planktonic cells were not statistically different could mean that eDNA release was slightly stimulated by a rise in temperature via active secretion or controlled cell lysis [19] in both the biofilm and planktonic cells and not necessarily as a resistance mechanism against the heat stress exposure. On the other hand, the observation that unlike the planktonic forms, the biofilm forms of S. epidermidis subjected to heat stress released significantly increased eDNA than the untreated controls strongly suggested a central role of eDNA in S. epidermidis biofilm cells resistance against the heat stress.

Further, there was no difference between eDNA released by $S$. epidermidis biofilm and planktonic cells subjected to sub-lethal $\mathrm{NaCl}$ stress. Unexpectedly, the $\mathrm{NaCl}$ stress treated $\mathrm{S}$. epidermidis biofilms released less eDNA than the untreated controls. A possible explanation for this unexpected observation could be inferred from previous studies which have shown that $\mathrm{NaCl}$ stress stimulates increased exopolysaccharide production in the ECM $[23,47]$ which might have resulted in strong bond formation between the eDNA and polyssacharides [52] rendering it largely inaccessible for quantification. Considered together, the present findings show that $\mathrm{NaCl}$ stress does not affect eDNA release by both $\mathrm{S}$. epidermidis biofilm and planktonic cells. The present finding concurs with a previous report on C. albicans biofilm subjected to $2 \mathrm{M} \mathrm{NaCl}$ [23]. However, C. albicans is a fungus hence may not inform bacterial biofilms response to osmotic stress. Further, the present findings are consistent with a previous report which showed that high salt concentration affects exopolysaccharide release by Halomonas variabilis and Planococcus rifietoensis [47]. However, the previous report only evaluated one component of the ECM that is the exopolysaccharide. The observation that neither S. epidermidis biofilm and planktonic cells nor the respective treated and untreated controls showed a significant difference in eDNA release suggested that eDNA does not play a role in osmotic stress resistance. In support of this interpretation, a study showed that osmotic stress does not produce eDNA richer ECM instead, exopolysaccharide and protein yield is enhanced to form a water-retaining layer around the biofilm cells [23] thus protecting the cells against dehydration. Moreover, it has been shown that autolysin (atl) gene, which is often associated with eDNA release is not affected by osmotic stresses [53] further implying that osmotic stress does not induce eDNA release.

Further, the present study showed that S. epidermidis biofilms enhance eDNA release in response to sub-lethal oxidative $\left(\mathrm{NaOCl}\right.$ and $\mathrm{H}_{2} \mathrm{O}_{2}$ ) stress exposure. This is consistent with previous reports, which showed that $\mathrm{H}_{2} \mathrm{O}_{2}$ stress exposure induced eDNA release by Streptococcus gordonii [34, 37] and C. albicans biofilm [23]. However, the previous reports only focused on planktonic forms of $S$. gordonii and a fungus, $C$. albicans hence may not inform eDNA release by bacterial biofilms in response to $\mathrm{H}_{2} \mathrm{O}_{2}$. 
Considered together, oxidative stresses damage genomic DNA triggering eDNA release by a subpopulation of bacterial cells [37]. Why oxidative stress-treated $S$. epidermidis biofilms released more eDNA than the corresponding planktonic cells is still not clear. One possible explanation could be related to the extracellular DNases released alongside eDNA in the following ways. First, unlike the planktonic cells, bacterial biofilm cells form small-protected pockets [21] that could be protecting most eDNA from DNases degradation. Second, bacterial biofilms eDNA is mostly bound to ECM [52] hence may not be easily accessible to the DNases. Third, bacterial biofilms produce relatively fewer DNases than the planktonic cells [54] thus minimizing the eDNA degradation. Fourth, bacterial biofilms induce release of proteolytic exoenzymes that inactivate the DNases locally [55]. Taken together, the explanations above suggest that eDNA and DNases release by bacterial biofilm cells are highly regulated processes. This implies that bacterial planktonic cells majorly release eDNA to be degraded for nutrients whereas bacterial biofilm cells induce eDNA release both as a nutrient source and for protection against the lethal effects of oxidative stresses.

An alternative explanation for the relatively increased eDNA release by S. epidermidis biofilm cells could be related to the high production of catalase enzyme [56] and ECM [12,57] which neutralizes and reacts with the $\mathrm{H}_{2} \mathrm{O}_{2}$ respectively. It has also been shown that $\mathrm{NaOCl}$ reacts with the organic components of the ECM thereby reducing its concentration [16]. Thus, the relatively increased eDNA release by $S$. epidermidis biofilm cells despite the potential exposure to lower concentrations of $\mathrm{NaOCl}$ and $\mathrm{H}_{2} \mathrm{O}_{2}$ strongly suggested an integral role of eDNA in the biofilm cells resistance to the oxidative stresses.

\section{Limitations}

A potential limitation of the present study is that although DNase appears to provide a more plausible explanation for the increased eDNA release by S. epidermidis biofilms challenged with the sub-lethal oxidative stresses, the presence of DNase was not quantitatively measured. Further studies with DNase $(+)$ controls and treatment groups may be necessary to confirm the direct link between eDNA and bacterial biofilm resistance to physico-chemical stresses.

\section{Conclusions}

In summary, S. epidermidis biofilms were less susceptible to physico-chemical stress induced by the four commonly recommended disinfectants than the corresponding planktonic forms. Thus, there is need to review the current disinfection guidelines to improve S. epidermidis biofilm disinfection efficiency. Further, $S$. epidermidis biofilms enhanced eDNA release in response to sub-lethal heat and oxidative stress exposure than the corresponding planktonic cells, suggesting a role of eDNA in the bacterial biofilms resistance to physicochemical stress exposure. Therefore, eDNA may be a potential target for novel anti-bacterial biofilm control and eradication strategies.

\section{Abbreviations \\ ATCC: American type culture collection; CFUs: Colony-forming units; dsDNA: Double-stranded DNA; ECM: Extracellular matrix; eDNA: Extracellular DNA; $\mathrm{H}_{2} \mathrm{O}_{2}$ : Hydrogen peroxide; HS: High sensitivity; MSA: Mannitol salt agar; $\mathrm{NaCl}$ : Sodium chloride; NaOCl: Sodium hypochlorite; OD: Optical density; rpm: Revolutions per minute; SEM: Standard error of the mean; TE: Tris- Ethylenediaminetetraacetic acid; TSB: Tryptic soy broth}

\section{Acknowledgements}

Authors wish to thank the director of Centre for Microbiology Research/ Kenya Medical Research Institute, Prof. Samuel Kariuki for generously donating the bacterial reference strains. Moreover, authors appreciate all the participants who provided samples for this study. Authors also thank the management and staff of the Kisumu County Hospital for facilitating sample collection.

\section{Funding}

This study was supported by a grant from National Commission for Science and Technology (NACOSTI), Kenya. The funding body had no role in study design, data collection, analysis and interpretation of data and in writing of the manuscript.

\section{Availability of data and materials}

All data generated or analyzed during this study are presented within this manuscript. All materials used in this study including raw data shall be availed upon reasonable request.

\section{Authors' contributions}

$\mathrm{COO}, \mathrm{PAO}, \mathrm{DMO}$, and $\mathrm{DOO}$ conceived and designed the experiments. COO collected samples, conducted the experiments and data analysis. COO, PAO, $\mathrm{DMO}$, and DOO interpreted the data and developed the manuscript arguments, reviewed and revised it. All authors read and approved the final manuscript.

\section{Ethics approval and consent to participate}

The use of samples from human participants and all the experimental protocols were reviewed and approved by the Maseno University Ethics Review Committee (Reference number: MSU/DRPI/MUERC/000187/15).

Further, permission to recruit outpatients at the Kisumu County Hospital in this study was granted by the Kisumu County Hospital, Kenya (Research file number: 74-2015). Written informed consents were obtained from all the participants for sample collection and further analyses before they participated in this study.

\section{Competing interests}

The authors declare that they have no competing interests.

\section{Publisher's Note}

Springer Nature remains neutral with regard to jurisdictional claims in published maps and institutional affiliations.

Received: 11 October 2017 Accepted: 23 April 2018

Published online: 02 May 2018

\section{References}

1. Jamal M, Tasneem U, Hussain T, Andleeb S. Bacterial biofilm: its composition, formation and role in human infections. RRJMB. 2015;4:1-14.

2. Hall-Stoodley L, Costerton J, Stoodley P. Bacterial biofilms: from the natural environment to infectious diseases. Nat Rev Microbiol. 2004;2:95-108. 
3. de la Fuente-Núñez C, Reffuveille F, Hancock R. Bacterial biofilm development as a multicellular adaptation: antibiotic resistance and new therapeutic strategies. Curr Opin Microbiol. 2013;16:580-9.

4. Høiby N, Ciofu O, Johansen H, Song Z, Moser C, Jensen P. The clinical impact of bacterial biofilms. Int J Oral Sci. 2011;3:55-65.

5. Olwal C, Ochiel D, Onyango D, Ang'ienda P. Bacterial biofilm cells quantification techniques: where is consensus in over two decades? J Microbiol Biotech Food Sci. 2017;7:168-73.

6. Joo H, Otto M. Molecular basis of in vivo biofilm formation by bacterial pathogens. Chem Biol. 2012;19:1503-13.

7. Linnes J, Hongyan M, Bryers J. Giant extracellular matrix binding protein expression in Staphylococcus epidermidis is regulated by biofilm formation and osmotic pressure. Curr Microbiol. 2013;66:627-33.

8. Rogers L, Fey D, Rupp L. Coagulase-negative staphylococcal infections Infect Dis Clin N Am. 2009:23:73-98.

9. McAuliffe L, Ellis R, Miles K, Ayling R, Nicholas R. Biofilm formation by Mycoplasma species and its role in environmental persistence and survival. Microbiology. 2006;152:913-22.

10. Wai S, Mizunoe Y, Takade A, Kawabata S, Yoshida S. Vibrio cholerae 01 strain TSI-4 produces the exopolysaccharide materials that determine colony morphology, stress resistance, and biofilm formation. Microbiology. 1998;64:3648-55.

11. Scher K, Romling U, Yaron S. Effect of heat, acidification, and chlorination on Salmonella enterica serovar typhimurium cells in a biofilm formed at the air-liquid Interface. Appl Environ Microbiol. 2005; 71:1163-8.

12. Peeters $E$, Nelis J, Coenye T. Evaluation of the efficacy of disinfection procedures against Burkholderia cenocepacia biofilms. J Hosp Infect. 2008;70:361-8.

13. Kubota H, Senda S, Tokuda H, Uchiyama H. Stress resistance of biofilm and planktonic Lactobacillus plantarum subsp. plantarum. Food Microbiol. 2009; 26:592-7.

14. Elkins J, Hassett D, Stewart P, Schweizer H, Mcdermott T. Protective role of catalase in Pseudomonas aeruginosa biofilm resistance to hydrogen peroxide. Appl Environ Microbiol. 1999;65:4594-600.

15. Steed K, Falkinham J III. Effect of growth in biofilms on chlorine susceptibility of Mycobacterium avium and Mycobacterium intracellulare. Appl Environ Microbiol. 2006;72:4007-11.

16. Stewart P, Rayner J, Roe F, Rees W. Biofilm penetration and disinfection efficacy of alkaline hypochlorite and chlorosulfamates. J Appl Microbiol. 2001;91:525-32.

17. Otto M. Staphylococcus epidermidis - the "accidental" pathogen. Nat Rev Microbiol. 2009;7:555-67.

18. Acker H, Dijck P, Coenye T. Molecular mechanisms of antimicrobial tolerance and resistance in bacterial and fungal biofilms. Trends Microbiol. 2014;20:1-8.

19. Okshevsky M, Meyer R. The role of extracellular DNA in the establishment, maintenance and perpetuation of bacterial biofilms. Crit Rev Microbiol. 2015;41:341-52.

20. Kaplan B, Izano A, Gopal P, Karwacki T, Kim S, Bose L. Low levels of B-lactam antibiotics induce extra-cellular DNA release and biofilm formation in Staphylococcus aureus. MBio. 2012;3:1-12.

21. Doroshenko N, Tseng B, Howlin R, Deacon J, Wharton J, Thurner P, et al. Extracellular DNA impedes the transport of vancomycin in Staphylococcus epidermidis biofilms preexposed to subinhibitory concentrations of vancomycin. Antimicrob Agents Chemother. 2014;58:7273-82.

22. Hathroubi S, Fontaine-Gosselin E, Tremblay D, Labrie J, Jacques M. Subinhibitory concentrations of penicillin $\mathrm{G}$ induce biofilm formation by field isolates of Actinobacillus pleuropneumoniae. Vet Microbiol. 2015;179:277-86.

23. Pemmaraju S, Padmapriya K, Pruthi P, Prasad R, Pruthi V. Impact of oxidative and osmotic stresses on Candida albicans biofilm formation. Biofouling. 2016:32:897-909.

24. Kloos W, Musselwhite M. Distribution and persistence of Staphylococcus and Micrococcus species and other aerobic bacteria on human skin. Appl Microbiol. 1975:30:381-95.

25. Divya G, Vyshnavi R. Incidence of biofilm producing Staphylococcus epidermidis isolated from clinical samples and skin of healthy individuals: a correlative study. Int J Multidiscip Res Dev. 2015;2:16-9.

26. França Â, Freitas A, Henriques A, Cerca N. Optimizing a qPCR gene expression quantification assay for Staphylococcus epidermidis biofilms: a comparison between commercial kits and a customized protocol. PLoS One. 2012;7:1-9.
27. Coraça-Huber D, Fille M, Hausdorfer J, Pfaller K, Nogler M. Staphylococcus aureus biofilm formation and antibiotic susceptibility tests on polystyrene and metal surfaces. J Appl Microbiol. 2012;112:1235-43.

28. Sobsey M. Managing water in the home: accelerated health gains from improved water supply [Internet]. World Health Organization; 2002 [cited 2017 Apr 26]. Available from: www.who.int/iris/handle/10665/67319.

29. Smith D, Stratton J. Food preservation, safety, and shelf life extension [Internet]. University of Nebraska; 2007 [cited 2014 Oct 31]. Available from: http://extension.unl.edu/assets/pdf/g1816.pdf.

30. Blum A, Null C, Hoffmann V. Marketing household water treatment: willingness to pay results from an experiment in rural Kenya. Water 2014;6:1873-86.

31. Linley E, Denyer S, McDonnell G, Simons C, Maillard J. Use of hydrogen peroxide as a biocide: new consideration of its mechanisms of biocidal action. J Antimicrob Chemother. 2012;24:1-8.

32. Abdallah $M$, Drider $D$, Chihib $N$. Effectives of growth temperature, surface type and incubation time on the resistance of Staphylococcus aureus biofilms to disinfectants. Appl Microbiol Biotech. 2014;98:2597-607.

33. Rodrigues D, Cerca N, Teixeira P, Oliveira R, Ceri H, Azeredo J. Listeria monocytogenes and Salmonella enterica Enteridis biofilms susceptibility to different disinfectants and stress-response and virulence gene expression of surviving cells. Microb Drug Resist. 2011;17:181-9.

34. Xu Y, Kreth J. Role of LytF and AtIS in eDNA release by Streptococcus gordonii. PLoS One. 2013;8:1-9.

35. Munn C, Marchant $H$, Moody A. Defences against oxidative stress in vibrios associated with corals. FEMS Microbiol Lett. 2008;281:58-63.

36. Strickler K, Fremier A, Goldgerg C. Quantifying effects of UV-B, temperature, and $\mathrm{pH}$ on eDNA degradation in aquatic microcosms. Biol Conserv. 2014;30:1-8.

37. Itzek A, Zheng L, Chen Z, Merritt J, Kreth J. Hydrogen peroxide-dependent DNA release and transfer of antibiotic resistance genes in Streptococcus gordonii. J Bacteriol. 2011;193:6912-22.

38. Pan X, Liu J, Zhang D, Chen X, Li L, Song W, et al. A comparison of five extraction methods for extracellular polymeric substances (EPS) from biofilm by using three dimensional excitation emission matrix (3DEEM) fluorescence spectroscopy. Water SA. 2010;36:111-6.

39. Davenport $E$, Call D, Beyenala $H$. Differential protection from tobramycin by extracellular polymeric substances from Acinetobacter baumannil and Staphylococcus aureus biofilms. Antimicrob Agents Chemother. 2014;58:4755-61.

40. Wingender J, Strathmann M, Rode A, Leis A, Flemming C. Isolation and biochemical characterization of extracellular polymeric substances from Pseudomonas aeruginosa. Meth Enzymol. 2001;336:302-14.

41. Francolini I, Donelli G. Prevention and control of biofilm-based medicaldevice-related infections. FEMS Immun Med Microbiol. 2010;59:227-38.

42. Garrett T, Bhakoo M, Zhang Z. Bacterial adhesion and biofilms on surfaces. Prog Nat Sci. 2008;18:1049-56.

43. Martinez L, Casadevall A. Cryptococcus neoformans biofilm formation depends on surface support and carbon source and reduces fungal cell susceptibility to heat, cold, and UV light. Appl Environ Microbiol. 2007;73: 4592-601.

44. Coenye T. Response of sessile cells to stress: from changes in gene expression to phenotypic adaptation. FEMS Immun Med Microbiol. 2010;59:239-52.

45. Liu C, Niu Y, Zhou X, Zheng X, Wang S, Guo Q. Streptococcus mutans copes with heat stress by multiple transcriptional regulons modulating virulence and energy metabolism. Sci Rep. 2015;5:1-12.

46. Filho J, Lopes R, Rivera I, Colwell R. Vibrio cholerae 01 detection in estuarine. J Plankton Res. 2011;33:51-62.

47. Qurashi A, Sabri A. Bacterial exopolysaccharide and biofilm formation stimulate chickpea growth and soil aggregation under salt stress. Braz J Microbiol. 2012;43:1183-91.

48. Cai L, De La Fuente L, Arias R. Biofilm formation by the fish pathogen Flavobacterium columnare: development and parameters affecting surface attachment. Appl Environ Microbiol. 2013;79:5633-42.

49. García-Contreras R, Nuñez-López L, Jasso-Chávez R, Kwan B, Belmont J, Rangel-Vega A, et al. Quorum sensing enhancement of the stress response promotes resistance to quorum quenching and prevents social cheating. ISME J. 2014:9:115-25.

50. Glynn A, O'Donnell S, Molony D, Sheehan E, McCormack D, O'Gara J. Hydrogen peroxide induced repression of icaADBC transcription and biofilm development in Staphylococcus epidermidis. J Orthop Res. 2009;27:627-30. 
51. Simões $L$, Simões M. Biofilms in drinking water: problems and solutions. RSC Adv. 2013;3:2520-33.

52. Song T, Duperthuy M, Wai S. Sub-optimal treatment of bacterial biofilms. Antibiotics. 2016:5:1-18.

53. Houston P, Rowe S, Pozzi C, Waters E, O'Gara J. Essential role for the major autolysin in the fibronectin-binding protein-mediated Staphylococcus aureus biofilm phenotype. Infect Immun. 2011;79:1153-65.

54. Tang L, Schramm A, Neu T, Revsbech N, Meyer R. Extracellular DNA in adhesion and biofilm formation of four environmental isolates: a quantitative study. FEMS Microbiol Ecol. 2013;86:394-403.

55. Whitchurch B, Tolker-Nielsen T, Raps C, Mattick S. Extracellular DNA required for bacterial biofilm formation. Sci. 2002;295:1487.

56. Jakubowski W, Walkowiak B. Resistance of oxidative stress in biofilm and planktonic cells. Braz Arch Biol Technol. 2015;58:1-6.

57. Jang I, Kim J, Park W. Endogenous hydrogen peroxide increases biofilm formation by inducing exopolysaccharide production in Acinetobacter oleivorans DR1. Sci Rep. 2016;6:1-6.

Ready to submit your research? Choose BMC and benefit from:

- fast, convenient online submission

- thorough peer review by experienced researchers in your field

- rapid publication on acceptance

- support for research data, including large and complex data types

- gold Open Access which fosters wider collaboration and increased citations

- maximum visibility for your research: over $100 \mathrm{M}$ website views per year 